\title{
EVALUATION OF FINANCIAL MANAGEMENT PATTERN OF THE PRODUCTION UNIT IN REFERRAL VOCATIONAL SCHOOL WITH ADVERSARY MODEL IN YOGYAKARTA SPECIAL REGION
}

\author{
Ambar Wahyu Astuti \\ Universitas Negeri Yogyakarta \\ Soenarto \\ Universitas Negeri Yogyakarta
}

\begin{abstract}
This study aims to determine the effectiveness of the implementation of Referral Vocational School (SMK Rujukan) program in financial management of production units in the DI. Yogyakarta province. This research was an evaluative research which described problem of financial management of production unit at SMK Rujukan. The approach used of this research were mixed methods which combined quantitative and qualitative research. The evaluation model of this research were an adversary model. An adversary evaluation model were an evaluation that seeked to uncover all the important aspects of the program being evaluated. The results showed that of the 5 SMK studied, there is only 1 SMK that had adequate financial management system of production unit, while 4 other SMK not yet adequated. Forms of protection to financial management of production units for SMK in the DI. Yogyakarta province had not been established yet. No school of the 5 schools studied, had implemented a pattern of financial management in accordance with applicable regulations.
\end{abstract}

Keywords: financial management pattern, production unit, referral Vocational School

Permalink: http://dx.doi.org/10.21831/jpv.v8i3.21448

Contact Ambar Wahyu Astuti ambarwa74@gmail.com

Universitas Negeri Yogyakarta, Jl. Colombo No. 1, Depok, Sleman 55281, Yogyakarta, Indonesia 


\section{INTRODUCTION}

Vocational education as education designed to develop skills, abilities, understanding, attitudes and work habits and appreciation needed by workers to enter and make progress in work based on benefits and productivity. Thompson (1973, p. 111) stated that the American Vocational Association defined vocational education as "Vocational education as education designed to developed skills, abilities, understandings, attitudes, work habits, and appreciations needed by workers to enter and make progress in employment on useful and productive basis " Vocational education not only touch skills, abilities, and understanding, but vocational education must also instill values in shaping attitudes, work habits, and appreciation for students, so that students can be productive and beneficial for themselves and their environment.

According to Mumpuni \& Widarto (2011) Mila Mumpuni and Widarto (2011) about the importance of managing production units were:

"In the Guidelines for Implementation the Production Units of Vocational High School, Production Units was formed strongly associated with three aspects are academic, economic, and social. Academic aspects of the implementation the Production Units of Vocational High School related with the process of teaching and learning in schools. The economic aspects, Production Units dispose to make financial resources for finance education and improve the welfare of citizens of the school. While the social aspect is expected the Production Units can realize the main task of the intellectual life of the nation's education and to character building with an entrepreneurship."

Based on this opinion the Production Unit was formed in three interrelated aspects, namely academic, economic and social. The implementation of the SMK production unit from the academic aspect is related to the teaching and learning process in schools. From an economic aspect, production units can become financial resources for financing education and improving the welfare of school citizens. Whereas from the social aspect, it is expected that the production unit can realize the main task of intellectual life of national education and build character with entrepreneurship.

Referral Vocational School (SMK Rujukan) were one of the Ministry of Education and Culture contained in the 2015-2019 Directorate of Vocational Development Strategic Plans. The definition of Referral Vocational School in the 2015-2019 Directorate of Vocational Development in the Strategic Plan (Direktorat Pembinaan SMK, 2015) is a superior vocational school in various aspects, so that it can be used as a reference for other SMKs. Some of the problems experienced by Vocational Schools that had the potential to become Referral Vocational Schools were, among others, inconsistencies between programs that became performance indicators for Referral Vocational Schools and the prevailing laws and regulations such as regulations on financial management of state revenues from the use of state facilities. One of the pros and cons that arised is the management pattern.

In the provision stated that products or services produced by government institutions that utilize state assets must be deposited in the state treasury. However, in its implementation, the current provisions had not specifically regulated the pattern of financial management in State-Owned Referral Vocational Schools, so that the development of production units which were the prerequisites for vocational education in general and Referral Vocational Schools in particular did not run optimally. Some Referral Vocational Schools had good and marketable product potential, but were not marketed, because the regulations were not clearly yet. Based on these considerations, it is necessary to evaluate the implementation of the Referral Vocational Program in the financial management pattern of the production unit with the adversary model, so that it could provide recommendations for future policy making of the Referral Vocational Program.

Another study about The Management Of Production Unit Of Vocational High School In The Field Of Building Program In Special Region Of Yogyakarta (A Case Study Of SMKN 2 Pengasih Kulonprogo) according to Gunadi \& Usman (2015) had a conclusion as follows:

the planning has not been implemented optimally; the obstacles in the planning, i.e. the absence of regular meetings, spe- 
cifically those discussing and the lack of documentations; not all the managers are involved; the organizing involves the distribution of the tasks, the delegation of tasks and authorities, as well as coordination; the obstacles in the personnel, inadequate facilities and infrastructure as well as the coordination; the implementation measures indicate the implementation functions applied are more like the implementation of the production process; the production unit has not functioned properly as a educational tool; the implementation is constrained by the workshop which also becomes a practicum place; the steps and the principles of supervision are only applied in terms of financial statements; the parties supervising the UPJ are the managers of the school UPJ, the managers of the department UPJ, and the head of the workshop; the supervision is constrained to the absence of SOP.

Based on these studies it can be concluded that the management of production units in SMKs had not run optimally because various factors, including planning, financial management, supervision, and SOP were not run properly and not available yet.

The purpose of this study was to determine the profile of Referral Vocational Schools which became a prerequisite for Referral Vocational School indicators which included the number of students, infrastructure facilities, vocational management, and entrepreneurshipbased learning. In the other side the purpose of this study was to find out the financial management of production units indicators which included the availability of legal protection, planning, governance and evaluation. SMK Rujukan that manages the production unit was said to be effective if it meets the indicator.

\section{RESEARCH METHODS}

This research was an evaluative study that described the problem of financial management of production units in SMK Rujukan. The evaluation model used in this study was the adversary model. The adversary evaluation model was an evaluation that seeked to reveal all important aspects of the program being evaluated.

Wolf (Stufflebeam \& Shinkfield, 1985, p. 266) stated that: "Basically, the approach in- volves the dialetic and legal processes. It attempts to examine openly issues surrounding a pro-position by presentation of cases for and against the proposition. The purpose is clarify. With proceedings completed, and the many facets surrounding the object of the evaluation illuminated, decision makers have sufficient, sound evidence to make rational decisions.

Basically, evaluation with this approach involved dialectics and legal/legal processes. This approach seeked to openly explain the issues that occur in a case proposition, where there were differences of opinion between the two parties. With a complete process, and many sides surrounding the illuminated evaluation object, the decision maker could make rational decisions and be accepted by both parties with sufficient evidence.

Production unit management was one form of entrepreneurial learning which is one of the preconditions for Referral Vocational Schools. The management of the production unit had not been able to run optimally, because it did not have a legal protection and a pattern that was in accordance with the current conditions of SMK yet.

The approach used in this study was a mixed approach with sequential explanatory that combined quantitative and qualitative research. The first stage of this evaluation were collect and analyze quantitative data, and then used the results of the analysis to plan the second stage, the qualitative stage. This study took quantitative data on the implementers of the Referral Vocational Program as those who supported and subsequently used the results to determine the parties that were opposite to the implementation of the Referral Vocational Program.

Quantitative research was carried out to collect data on the financial management conditions of the production units of Referral Vocational Schools in 5 Provincial Vocational Schools in DI. Yogyakarta, included SMK 2 Depok, 6 Yogyakarta Vocational Schools, 2 Wonosari Vocational Schools, 1 Kalasan Vocational High School, and 2 Sewon Vocational High School. Furthermore, qualitative research was carried out in two stages, namely holding a meeting between the managers of the production units of the SMK and the Provincial Education, Youth and Sports Department. Yogyakarta, and followed the Focus Group Discussion which discussed the financial 
management of the production unit organized by the Provincial Education, Youth and Sports Department. Yogyakarta by inviting resource persons from the Head of Compassionate Vocational School 2, Vocational Field Lecturers, and Regional Finance and Revenue Management Services of Yogyakarta Province.

\section{RESEARCH RESULTS AND DISCUSSION}

The results of research on Profile of Referral and Financial Management Vocational Schools in 5 Vocational Schools are shown in Figure 1.

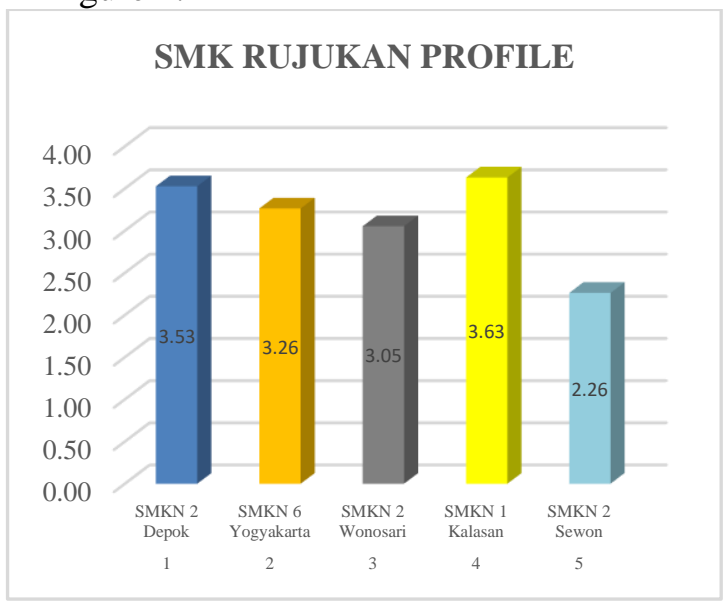

Figure 1. SMK Rujukan Profile

Profile Values of Referral Vocational High Schools from each Vocational School are Depok Vocational High School 2 with a grade of 3.53 with the Appropriate category, Vocational High School 6 Yogyakarta gets a score of 3.26 in the Appropriate category, Vocational High School 2 Wonosari gets a score of 3.05 in the Appropriate category, and Vocational High School 1 Kalasan gets a score of 3.63 in the category Appropriate, so that it meets the requirements as a Referral Vocational School. Whereas SMK 2 Sewon with a value of 2.26 in the category of Inappropriate.

In the spider web (spyder web) diagram of the Referral Vocational Profile are shown in Figure 2. Based on the results of the Figure 2, there were 4 schools that had fulfilled the requirements as Referral Vocational Schools in the Appropriate category and 1 school has not met the requirements as a Referral Vocational School. 4 schools that have fulfilled these requirements, namely SMK 2 Depok, SMK 6 Yogyakarta, SMKN 2 Wonosari, and SMKN 1 Kalasan.

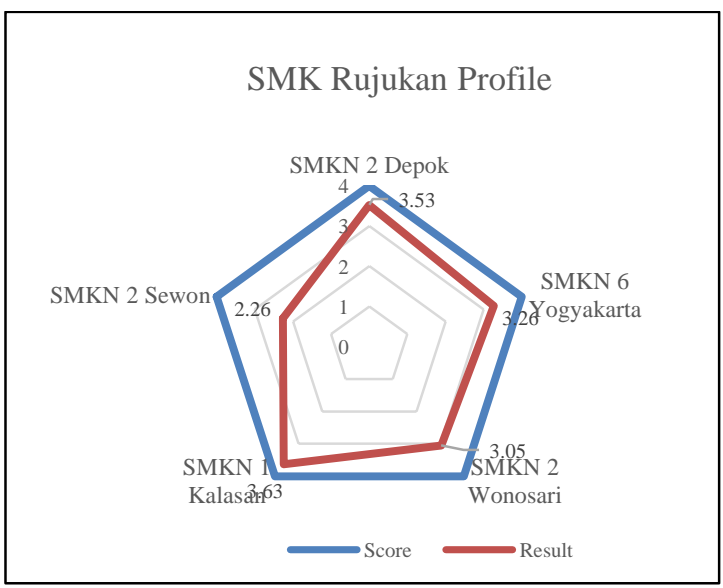

Figure 2. SMK Rujukan Profile

Based on these two data, of the 5 schools studied there were 4 Vocational Schools that had qualified as Referral Vocational Schools, namely SMKN Depok 2, SMKN 6 Yogyakarta, SMKN 2 Wonosari, and SMKN 1 Kalasan. Whereas SMKN 2 Sewon had not fulfilled the requirements as a Referral Vocational School.

Research Results on Financial Management of the Production Unit are shown in Figure 3.

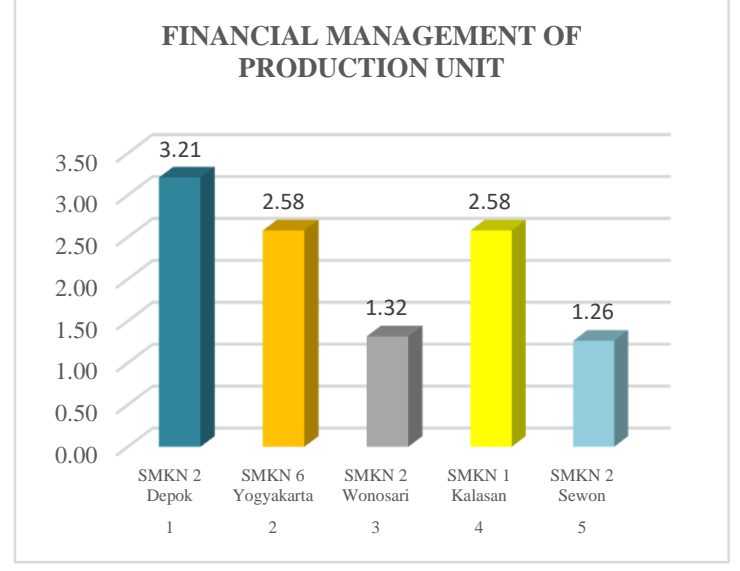

Figure 3. Financial Management of the Production Unit

Score of financial management production units of each Vocational High School were SMKN 2 Depok obtained a score of 3.32 in the Appropriate category, SMKN 6 Yogyakarta obtained a score of 2.58 in the Less Compliant category, SMKN 2 Wonosari obtained a score of 1.32 in the Unsuitable category, SMKN 1 Kalasan obtained the score was 2.58 in the Less Compliant category, and SMKN 2 Sewon had a score of 1.26 in the category of Not Appropriate. 


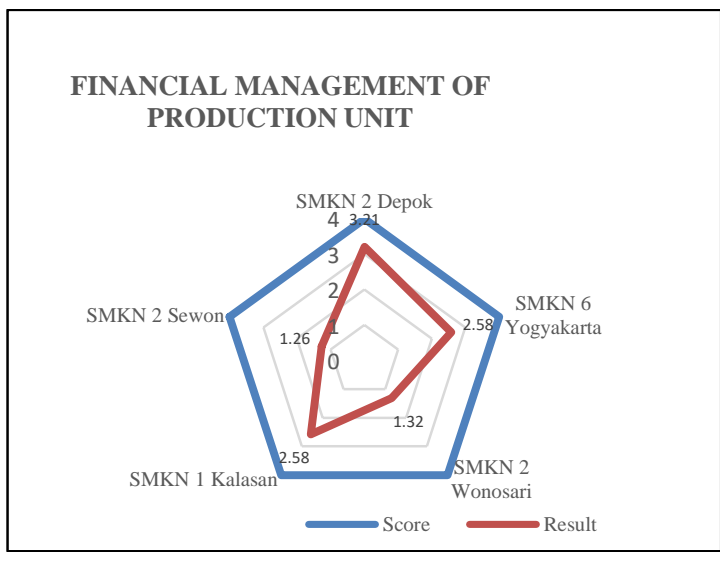

Figure 4. UP Management Production

Based on the data above it can be concluded that from 5 schools studied 1 school (SMKN 2 Depok) had implemented financial management of the production unit according to adequate management provisions, while 4 other schools (SMK 6 Yogyakarta, SMKN 2 Wonosari, SMKN 1 Kalasan, and SMKN 2 Sewon) had not managed the financial unit of production in accordance with the provisions of adequate financial management.

Based on the above data, it can be described in Table 1.

Table 1. Data on Financial Management of Production Unit

\begin{tabular}{clcc}
\hline & & \multicolumn{2}{c}{ Score } \\
NO & \multicolumn{1}{c}{ Respondent } & $\begin{array}{c}\text { Profile of } \\
\text { SMK } \\
\text { Rujukan }\end{array}$ & $\begin{array}{c}\text { Financial } \\
\text { Management } \\
\text { Producition Unit }\end{array}$ \\
\hline 1 & SMKN 2 Depok & 3,53 & 3,21 \\
2 & SMKN 6 Yogyakarta & 3,26 & 2,58 \\
3 & SMKN 2 Wonosari & 3,11 & 1,32 \\
4 & SMKN 1 Kalasan & 3,63 & 2,58 \\
5 & SMKN 2 Sewon & 2,42 & 1,26 \\
\hline
\end{tabular}

Based on these data it could be conclude that of the 5 schools studied, only 1 (one) school, namely SMK 2 Depok, was categorized as Referral Vocational School and had sufficient financial management of the production unit (Appropriate). While the other 4 SMKs did not have sufficient financial management.

The total score obtained for 2 (two) aspects consisting of referral vocational profiles and financial management of the production units of each vocational school were SMKN 2 Depok obtained score 3,42 (Appropriate) on Vocational High School Profile and Financial Management Production Unit 3,21 (Appropriate). SMKN 6 Yogyakarta obtained SMK
Rujukan Profile 3.26 (Appropriate) and 2,58 (Less Appropriate) Financial Management Production Unit. SMKN 2 Wonosari obtained) SMK Rujukan Profile 3.11 (Appropriate and Financial Management Production Unit 1, 32 (Not Appropriate). SMK 1 Kalasan obtained SMK Rujukan Profile 3,63 (Appropriate) and Financial Management Production Unit 2,58 (Inadequate), and SMKN 2 Sewon obtained SMK Rujukan Profile 2,42 (Inadequate) and Financial Management of Production Unit 1, 26 (Not Appropriate).

Based on these data it could be conclude that of the 5 schools studied, only 1 (one) school, namely SMK 2 Depok, was categorized as Referral Vocational School and had sufficient financial management of the production unit (Appropriate). Whereas based on the image shown in the spider web diagram on the results of the evaluation of Profile of Referral Vocational Schools and Financial Management of Production Units, schools that had high scores in the Profile of Referral Vocational Schools (SMK Rujukan) had a more adequate Production Unit Financial Management than those with lower grades. Whereas SMKs that had lower SMK Rujukan Profile scores tend to have lower Production Unit Financial Management score.

Discussion was the next step in this research. The discussion was conducted to discuss the financial management pattern of the production unit in 2 (two) stages as follows:

1. Discussion with Respondents and the Provincial Education Office

This discussion activity was held on September 14, 2017 at the UNY Postgraduate Program. The discussion forum was attended by production unit managers of SMKN 2 Wonosari, SMK 6 Yogyakarta, SMK 1 Kalasan, SMKN 2 Sewon, and Head of Vocational Secondary Education Section of the Department of Education, Culture, Youth and Sports of the Special Province of Yogyakarta. The agenda of the meeting was the presentation of the results of research on several schools that were the object of research. The current production unit Financial Management Patterns, alternative financial management patterns suitable for SMK production units (Regular Satker / BLUD), and how the production unit management policy would be developed by the Provincial Education Office. The results of this discussion are shown in Table 2. 
Table 2. Discussion Result of Respondent and Department of Education, Culture, Youth and Sports of the Special Province of Yogyakarta

\begin{tabular}{|c|c|c|c|}
\hline No & SMK & $\begin{array}{l}\text { Department of Education, Culture, } \\
\text { Youth and Sports of the Special } \\
\text { Province of Yogyakarta }\end{array}$ & Solusi \\
\hline 2. & $\begin{array}{l}\text { Schools had no flexibility in financial } \\
\text { management of production units. } \\
\text { School Production Units had the potential } \\
\text { product to be developed better such as } \\
\text { before there are non-tax state revenue rules. } \\
\text { The production unit was more developed } \\
\text { into a place of practical learning currently }\end{array}$ & $\begin{array}{l}\text { 1.The flexibility of financial } \\
\text { management of the production } \\
\text { unit could be obtained if the } \\
\text { school applied BLUD, while the } \\
\text { Office did not have a pattern that } \\
\text { is in accordance with the current } \\
\text { conditions yet, so further } \\
\text { assessment is needed. }\end{array}$ & \multirow{2}{*}{$\begin{array}{l}\text { The Office would } \\
\text { conduct a Focus } \\
\text { Group Discussion } \\
\text { which present } \\
\text { relevant parties } \\
\text { including } \\
\text { vocational schools } \\
\text { to assessment } \\
\text { which pattern was } \\
\text { suitable for SMK }\end{array}$} \\
\hline 4. & $\begin{array}{l}\text { Schools had no flexibility in financial } \\
\text { management of production units as before } \\
\text { A legal protection governing the } \\
\text { management of production units need to be } \\
\text { created, so schools could manage } \\
\text { production units safely }\end{array}$ & $\begin{array}{l}\text { 2. The Office was considering a } \\
\text { pattern of management of } \\
\text { production units that are suitable } \\
\text { for Vocational Schools, between } \\
\text { Public Service Agencies (BLU) } \\
\text { or Regular Satkers }\end{array}$ & \\
\hline
\end{tabular}

\section{Focus Group Discussion with the Education Office of the Education, Youth and Sports Agency of the Special Province of Yogyakarta.}

This activity was organized by the Field of Secondary and Higher Education, Department of Youth and Sports Education of the Special Province of Yogyakarta on September 22, 2017 at the Department of Youth and Sports Education of the Special Province of Yogyakarta. This meeting presented Dr. Toto Sugiharto Arifin, M.Hum. (Teaching Factory), Head of SMKN 2 Pengasih, and the Head of the Legal Bureau of the Regional Revenue and Financial Management Office. The agenda of the activity were information about Teaching Factory, Implementation of Teaching Factory in SMK 2 Pengasih, Kulon Progo, and Management of SMK Production Units from the Provincial Revenue, Management and Financial Assets Office of DI. Yogyakarta (Amin Purwani, S.H, M.Ed. Cv).

Representative of the school asked the rules regarding the financial management of the unit were very important to be realized. Most of the SMKs had income from the production unit. The school wanted that there would be flexibility in financial management of the production unit, so the income can be used directly in supporting the operations of the production unit. The response given by the resource person regarding the financial management rules of the production unit was as follows: (1) The transfer of the SMA / SMK authority to the Provincial Service has not regulated the management of SMK production units regulation, (2) in drafting legal rules, such as in the management of production units, local governments need to take several steps, namely: (a) verifying whether there was already a regulation or not that regulates the management of the previous production unit; (b) mapping of existing regulations; (c) identification of data needed;(d) checking wether there exceptions to the conditions that will be made; (3) The Provincial Dikpora Service had not been able to establish the right pattern, because further studies are needed

The next response was related to the flexibility in financial management of the production unit, which the income could be used directly in supporting the operations of the production unit as follows:

First, The current financial management pattern was the usual satker pattern. The usual satker pattern was a pattern in which every domestic revenue arising as a result of service to the community carried out by Government Agencies must be deposited in the state treasury. The Provincial Dikpora Office need to have an acceptance treasurer in charge of depositing production unit income received by the school through the treasury of admission 
assistants who are in the school or in the dikmen in the district / city.

Second, in the case of financial management using the BLUD pattern, schools must fulfill the substantive, administrative and technical requirements stipulated in the Peraturan Menteri Dalam Negeri No. 61 of 2007 (Menteri Dalam Negeri, 2007) concerning Technical Guidelines for the Management of Regional Public Service Bodies.

First, In terms of the pattern of financial management of the ordinary satker, the costs incurred by the production unit such as maintenance, honoraria, etc. could be budgeted in the School Budget and Expenditure Plan. Revenue received by the production unit must be immediately deposited to the State treasury within 1 day.

Second, In the case of BLUD financial management patterns, schools must have funding independence. Management of production unit assets was separate from school management. There is independence in its management. Revenue received can be directly used for production unit operations.

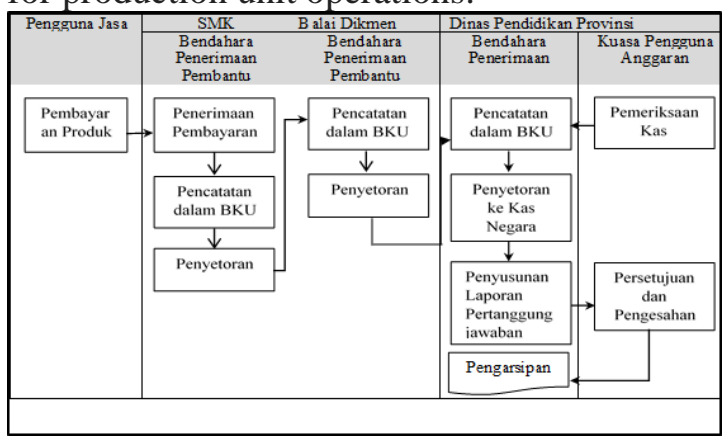

Figure 5. Work Unit (Satker Biasa)

Management Pattern

The diagram above explained that service users made payments for goods/services provided by vocational schools. The income received by the service user was recorded in the general cash book (BKU) by the treasurer receiving the school assistant. The treasurer of maid receipts must immediately deposit the income received to the treasurer of the auxiliary receipt, the Balai Dikmen within one working day from the time the income was received. Furthermore, the treasurer of the auxiliary assistant recorded the receipt to the BKU and deposited it to the Receiving Treasurer at the DI Provincial Office of Dikpora. Yogyakarta. Receiving Treasurer must imme- diately deposit to the State treasury within 1 business day of receipt of income

In the usual management pattern of the satker, all costs incurred from the cooperation carried out had been budgeted in the School Budget Plan (RAPBS) each year. The production unit must prepare a budget to meet the cost needs in the coming year such as materials, tools, honorariums, etc. and submitted to school. The School had responsibility to budget the cost of procuring, maintaining and maintaining state property. The advantages of this pattern, the operational costs of the production unit could be accommodate in the school budget. The weakness of the financial management of the production unit was not independent, it was still under the control of the school. If there was a need for materials and equipment, maintenance of buildings and equipment in the production unit, the management must wait for approval and budget from the school.

The financial management pattern of the Public Service Agency/Regional Public Service Agency (BLUD) provided flexibility in the form of flexibility to implement sound business practices. The aim was to improve services to the community in order to promote public welfare and educate the life of the nation, as an exception to the provisions of regional financial management in general.

School would implement BLUD management patterns in whose production units must meet the substantive, technical and administrative requirements as stipulated in Article 4 of the Peraturan Menteri Dalam Negeri No. 61 of 2007. Substantive requirements were fulfilled if the tasks and functions of the Regional Work Unit (SKPD) or work unit were operational in carrying out public services that produced semi public goods/services. The public services referred to in article 5 paragraph (1) related to (1) the provision of public goods and /or services to improve the quality and quantity of community services, (2) the management of certain regions/regions for the purpose of improving the economy of the community and public services, and/or (3) management of special funds in order to improve the economy and/or public services. In this case some schools have had products in the form of semipublic goods/services to improve the eco-nomy and public services. However, Article 6 states that the provision of goods and/or public ser- 
vices as referred to in Article 5 in paragraph (2) letter a, is prioritized for health services.

The technical requirements referred to in article 4, according to article 9 can be fulfilled if (1) the performance of services in the field of duty and its functions were worthy of being managed and enhanced its achievements through BLUD on the recommendation of the regional secretary for SKPD or the head of SKPD for work units and (2) SKPD financial performance or a healthy work unit. In the event that the school would propose the financial management of its production unit to become a BLUD, there must be a recommendation from the Provincial Secretary of DI. Yogyakarta to the principal.

Criteria worthy of being managed in Article 9 letter a included (1) having the potential to improve service delivery effectively, efficiently and productively, and (2) having technical specifications related to direct services to public services to the public. While the sound financial criteria in article 9 letter $b$ are indicated by the level of income ability of services that tend to increase and be efficient in financing expenses. Based on the above criteria, then of the 5 Vocational Schools studied showed that there were products/services provided by vocational schools that are directly related to public services such as hospitality, but more products/services were not directly related to public services in the community. Based on the results of observations on reports and interviews, the SMKs studied were not yet analyzing on the ability of income and efficiency of costs incurred. The financial statements were still simple, record only income and expenses.

Administrative requirements in Article 4 are fulfilled, if the SKPD or Work Unit made and submited documents which include: (1) a statement of ability to improve service, financial and benefit performance for the community, (2) governance patterns, (3) business strategic plan, (3) minimum service standards, (4) principal financial statements or financial statement prognosis/projections; and, (5) latest audit report or statement of willingness to be independently audited.

Based on the above provisions, Vocational Schools applying for BLUD need to prepare the document. In the explanation of the next article the statement of commitment as referred to in article 11 letter a for BLUD-work units was made by the principal and known by the Head of the Provincial Dikpora Office. While the pattern of governance as stipulated in article 11 letter b was an internal regulation made by the work unit/school that would implement the BLUD.

Based on the observations and datas, there were 4 Vocational Schools that had standard operating procedures regarding the production units established in the ISO 9001 quality management system.

The next requirement in article 14 , the school must prepare a Business Strategic Plan which included a five-year strategic plan that consists of a vision, mission, strategic program, measurement of performance achievement, performance achievement plan, five-year achievement plan and five-year financial project from school. Schools must also set a minimum service standard that included minimal limits on the type and quality of basic services. Based on the observations in 5 Vocational Schools, in general they had had a school development plan, but no one had specifically had a production unit business plan.

The principal financial statements based on article 16 paragraph (1) that must be prepared by the school consists of budget realization reports, balance sheets, and financial statement records. The principal financial statements as stipulated in paragraph (1) of the article were prepared based on the accounting system that applied to local governments. The financial prognosis/projection as referred to in article 11 letter e included the prognosis/projection of the operational report and the prognosis/balance sheet projection. Based on observations and existing documents, the report on financial management of production units in the researched vocational schools were still simple, no school had implemented accounting standards issued by the Indonesian accounting professional association as required in Article 16 paragraph (4). While the prognosis/projection report does not yet exist.

The final audit report on the last year's financial statements by the external auditor must be submitted before the SKPD or work unit (in this case the school) was proposed to apply PPK-BLUD as stipulated in article 17. In the event that the SKPD or work unit was not yet ready, then the Head of the SKPD or head work units/principals who would apply BLUDs 
were required to make a statement prepared to be independently audited.

Form of protection for the financial management of production units had not been established for SMK in the province of DI. Yogyakart. Of the 5 schools studied there were no schools had implemented financial management patterns in accordance with the applicable regulations.

The submission mechanism for implementing PKK-BLUD according to articles 18 and 19 was as follows:

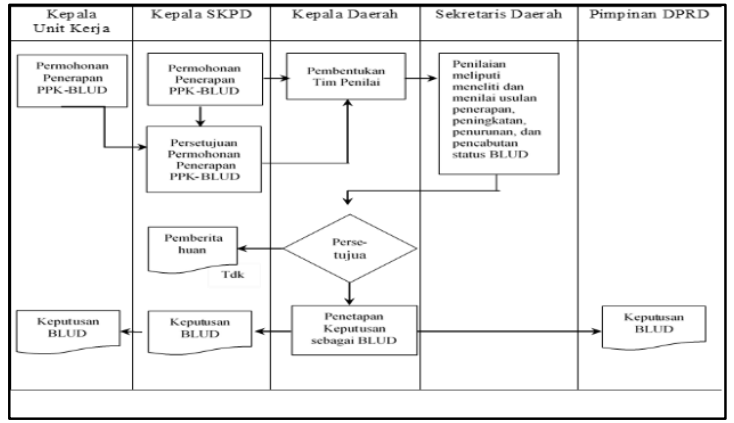

Figure 6. Work Unit (Satker Biasa) Management Pattern

Based on the above mechanism, it could be seen that the work unit or satuan kerja that would implement the BLUD need to take steps starting from the work unit or SKPD that would implement the BLUD Financial Management Pattern (PKK), submitting an application for the implementation of PKK-BLUD to the Regional Head. Furthermore, the Governor as the Regional Head would form an assessment team chaired by the Regional Secretary. The Assessment Team would research and assess the proposed implementation, improvement, decline and revocation of BLUD status. The Regional Head gave approval or rejection based on the results of the assessment. The Regional Head made the decision of the school or satker that applied PKK-BLUD and submited the decision to the school or relevant satker no later than 1 month after the date of stipulation

BLUD status could be given in full or in stages status depending on the results of the assessment. The status of full BLUD according to article 24 was given if all substantive, administrative and technical requirements. The status of a gradual BLUD according to Section 26 could be increased to full at the suggestion of the BLUD leader to the Regional Head in accordance with the mechanism for deter- mining BLUD. The status of a gradual BLUD according to article 27 was given flexibility at certain limits relating to the amount of funds that could be managed directly, managing goods, managing accounts receivable, as well as formulating standards, policies, systems and procedures for financial management. The status of a gradual BLUD according to article 28 is not given flexibility in terms of investment management, debt management, and procurement of goods and/or services.

\section{CONCLUSION}

Based on the results of mixed methods research with the advesary model with data collection techniques, observation, interviews and documentation studies carried out in 5 (five) SMK Rujukan in Yogyakarta Province regarding the financial management of production units, it can be concluded as follows.

The value of financial management of the production units of each vocational school was SMK 2 Depok with score 3.21 in the corresponding category, SMKN 6 Yogyakarta with sore 2.58 in the category of inappropriate, SMKN 2 Wonosari with score 1.32 in the category of inappropriate, SMK 1 Kalasan with score 2.58 in the category of Inadequate, and SMK 2 in Sewon with score of 1.26 in the category of Not Appropriate. Based on these results there were only one school, namely SMKN 2 Depok which had adequate financial management of the production unit, while the other four schools still did not manage an adequate production unit. This shows that the financial management of the Referral Vocational Production Unit in DI Yogyakarta Province had not been effective.

The pattern of financial management of production units had not been established in the SMK Rujukan Program in the DI Yogyakarta province. There was no form of legal protection provided by the government in the financial management of production units for Referral Vocational Schools in the DI Yogyakarta province.

The role of relevant government agencies was quite good in providing legal protection solutions to the financial management of the production units of Referral Vocational Schools in DI Yogyakarta Province. The Yogyakarta Education, Youth and Sports Agency was collaborating with the Provincial DI Re- 
venue, Management and Asset Management Office Yogyakarta the role of relevant government agencies in providing legal protection solutions to financial management of production units of SMK Rujukan in Yogyakarta Province. The institution was reviewing regulations that were in line with the financial management of production units with two alternatives, namely Financial Management Patterns of the Regular Satker Production Unit or Regional Public Service Agency.

The suggestions that can be given are as follows: (1) Regulations concerning the pattern of financial management need to be immediately realized as a legal protection for SMK in managing production units to be more optimal, safe and accountable, (2) The financial management of the ordinary satker became the most suitable alternative to the current condition of the SMK, when viewed from the differences in the financial management of the regular Satker and BLUD and the results of the above studies, (3) Financial management of vocational production units could be directed to BLUD in the future. However, for the initial stage it was necessary to establish several model schools that were selected based on product excellence and governance to become BLUDsWork units under BLUD-Satkers namely the Education, Youth and Sports Service of the Province of DI Yogyakarta, (4) The Education, Youth and Sports Office needs to set the criteria for schools that would be a model for applying BLUD financial management patterns.

\section{REFERENCES}

Direktorat Pembinaan SMK. (2015). Rencana strategis Direktorat Pembinaan SMK 2015-2019. Jakarta: Penerbit
Kementerian Pendidikan dan

Kebudayaan Direktorat Jenderal

Pendidikan Dasar dan Menengah

Direktorat Pembinaan Sekolah

Menengah Kejuruan.

Gunadi, A., \& Usman, H. (2015). Pengelolaan unit produksi SMK Negeri rumpun bangunan di Daerah Istimewa Yogyakarta (studi kasus SMKN 2 Pengasih Kulonprogo). Jurnal

Pendidikan Vokasi, 5(2). https://doi.org/10.21831/jpv.v5i2.6381

Menteri Dalam Negeri. Peraturan Menteri Dalam Negeri Nomor 61 Tahun 2007 tentang Pedoman Teknis Pengelolaan Keuangan Badan Layanan Umum Daerah (2007).

Mumpuni, M., \& Widarto. (2011). The production units organizational structure for vocational high school in the form of "Koperasi": dream or solution. In Confrence on Vocational Education Training (ICVET) 2011. Yogyakarta State University.

Stufflebeam, D. L., \& Shinkfield, A. J. (1985). Systematic evaluation a selfinstructional guide to theory practice, United State America: Kluwer-Nijhoff Publishing.

Thompson, J. F. (1973). Foundations of vocational education, social and philosophical concepts. New Jersey: Prentice Hall. 